\title{
KEDUDUKAN HUKUM PERJANJIAN KREDIT DENGAN JAMINAN TEMPAT USAHA
}

\author{
Rheza Narendra Putra Pratama \\ E-mail: rhezanarendrapp8@gmail.com \\ Mahasiswa S1 Program Studi Ilmu Hukum Fakultas Hukum Universitas Sebelas Maret Surakarta \\ Suraji \\ E-mail: surajifhuns@staff.uns.ac.id \\ Dosen Fakultas Hukum Universitas Sebelas Maret Surakarta
}

\begin{abstract}
This article discusses the legal standing of credit agreement with business place as the collateral. This study uses normative or doctrinal legal research methods that act prescriptively and applied. This study uses sources of primary and secondary legal materials. The analysis technique used is the syllogism method that uses deductive thinking patterns. Based on the results of this study it can be concluded. Credit agreement with business place as collateral commonly found nowadays. Mostly micro small and medium business operators as the debtors who have limited capital and limited ownership of object which could burdened by institutionalized collateral rights legally. Whereas, generally business place which proposed as the collateral not owned by the business operators but owned by other party. Practically bank as creditors agreed these credit lending because it has good economic value. Conseuently the legality of these credit agreement as the basis and the business place as the collateral be important.
\end{abstract}

Keywords: Legal Standing; Credit Agreement; Collateral; Business Place

\begin{abstract}
Abstrak
Artikel ini bertujuan untuk mengetahui kedudukan hukum perjanjian kredit atau utang piutang yang disertai jaminan berupa tempat usaha. Penelitian ini menggunakan metode penelitian hukum normatif atau doktrinal yang bersifat preskriptif dan teknis. Penelitian ini menggunakan sumber bahan hukum primer dan sekunder. Teknik analisis yang digunakan yaitu dengan metode silogisme yang menggunakan pola berpikir deduktif. Berdasarkan hasil penelitian ini dapat disimpulkan bahwa perjanjian kredit dengan bentuk seperti ini jamak ditemui praktiknya sekarang ini. Biasanya yang bertindak sebagai debitor merupakan pemilik usaha mikro kecil dan menengah yang memiliki keterbatasan modal dan keterbatasan kepemilikan benda yang bisa dibebani hak jaminan yang sudah terinstitusionalisasi secara hukum. Padahal biasanya tempat usaha yang diajukan menjadi jaminan bukan merupakan kepemilikan langsung dari para pelaku usaha, akan tetapi milik pihak lain. Praktiknya bank sebagai kreditor juga menyetujui pemberian kredit seperti ini karena dianggap memiliki nilai ekonomis yang baik. Oleh karena itu aspek legalitas perjanjian kredit yang mendasarinya serta tempat usaha yang dijadikan jaminan menjadi penting.
\end{abstract}

Kata Kunci: Kedudukan Hukum; Perjanjian Kredit; Jaminan; Tempat Usaha

\section{A. Pendahuluan}

Utang sebagai salah satu sumber dana dapat diperoleh dari lembaga keuangan baik lembaga perbankan maupun non bank, lembaga pembiayaan, dan pasar uang. Dalam praktek pemberian utang di dalam dunia perbankan, lazim didahului dengan perjanjian utang piutang atau perjanjian kredit. Proses utang piutang antara kreditur dan debitur memerlukan suatu jaminan guna memastikan adanya pengembalian utang (Iming M. Tesalonika, 2001: 7). Lembaga keuangan merupakan lembaga perantara dari pihak yang kelebihan dana (surplus of funds) dengan pihak yang kekurangan dana (lack of funds) yang memiliki fungsi sebagai perantara keuangan masyarakat (financial intermediary) (Neni Sri Imaniyati, 2010: 2). 
Menurut data World Bank, hanya 17 persen dari penduduk yang mempunyai akses kredit (Muliaman D. Hadad, 2017: 5-7). Hal ini termasuk para pelaku usaha mikro atau pedagang kecil. Pedagang kecil yang memiliki aset yang juga sedikit, tentu saja dalam prakteknya sulit mendapatkan pinjaman untuk menjalankan usahanya. Dengan kata lain aset yang dimiliki pedagang kecil dapat dikatakan kurang untuk dijadikan jaminan dalam perjanjian kredit yang beresiko tinggi. Padahal jaminan memegang peranan penting dalam kegiatan perkreditan di bank yang mana mensyaratkan adanya suatu jaminan yang harus dipenuhi debitur jika ingin mendapatkan pinjaman.

Sekarang inipun banyak macam jaminan yang juga diatur oleh negara dalam undang-undang. Di luar yang diatur di dalam Kitab Undang-Undang Hukum Perdata (KUHPer) ada Hak Tanggungan yang diatur dalam Undang-Undang Nomor 4 Tahun 1996, Fidusia yang diatur oleh UndangUndang Nomor 42 Tahun 1999, dan Resi Gudang yang diatur Undang-Undang Nomor 9 Tahun 2006 sebagaimana diubah dengan Undang-Undang Nomor 9 tahun 2011. Meskipun demikian banyak kendala penyaluran kredit terhadap pedagang kecil atau pelaku usaha mikro. Para pelaku usaha mikro yang menginginkan tambahan modal usaha tidak semuanya memiliki jaminan berupa benda yang lembaga penjaminannya telah diatur dalam peraturan perundang-undangan (Nurul Masfuhah, 2016: 254). Bahkan seringkali para pelaku usaha ini hanya memiliki jaminan berupa tempat mereka berdagang padahal tempat tersebut bukan milik para pedagang itu sendiri. Para pedagang hanya memiliki izin untuk menggunakannya. Secara teoritis, tempat usaha yang bukan merupakan milik para pedagang bukan merupakan objek jaminan menurut hukum kebendaan yang berlaku di Indonesia. Akan tetapi pada praktiknya, izin pemakaian kios atau tempat usaha dapat dipergunakan sebagai jaminan atas kredit perbankan (Nurul Masfuhah, 2016: 255).

Akibat dari praktik hukum yang terjadi secara masif di masyarakat dan belum ada norma hukum yang secara tegas mengaturnya, maka potensi terjadinya ketidakpastian hukum (rechtsonzekerheid) di masyarakat juga tinggi. Berdasarkan praktik yang berjalan di masyarakat maka atikel ini menguji praktik tersebut dengan norma hukum yang ada dan yang sebaiknya ada untuk memfasilitasinya.

\section{B. Metode Penelitian}

Jenis penelitian yang digunakan dalam penulisan hukum ini adalah penelitian hukum normatif atau biasa dikenal dengan hukum doktrinal, yaitu penelitian yang dilakukan dengan cara meneliti bahan pustaka yang terdiri dari bahan hukum primer, bahan hukum sekunder dan bahan hukum tersier. Menurut Peter Mahmud Marzuki, semua penelitian yang berkaitan dengan (legal research) adalah selalu normatif. Jika tipe penelitian ini harus dinyatakan dala bentuk tulisan cukup dikemukakan bahwa penelitian ini adalah penelitian hukum. Dengan adanya pernyataan demikian maka sudah jelas bahwa penelitian tersebut bersifat normatif. Hanya saja pendekatan dan bahanbahan hukum yang digunakan harus dikemukakan (Peter Mahmud Marzuki, 2014: 55-56).

Dalam Penelitian hukum ini, penulis menggunakan pendekatan perundang-undangan (statute approach) yaitu pendekatan dengan mencari peraturan perundang undangan yang terkait. Karena di dalam penelitian hukum ini, penulis akan memecahkan permasalahan hukum berdasarkan dengan peraturan perundang-undangan yang berlaku.

Teknik analisis data menggunakan menggunakan teknik analisis data kualitatif dengan menggunakan, mengelompokkan, dan menyeleksi data yang diperoleh dari penelitian lapangan, kemudian dihubungkan dengan teori-teori, asas-asas, dan kaidah-kaidah hukum yang diperoleh dari studi kepustakaan.

\section{Hasil Penelitian dan Pembahasan}

Jaminan kebendaan pada dasarnya memberikan kedudukan yang lebih baik kepada kreditor pemegang jaminan tersebut daripada kreditor-kreditor lainnya. Pengaturan tentang hukum benda dalam Buku II KUHPerdata ini menggunakan sistem "tertutup", artinya orang tidak diperbolehkan mengadakan hak-hak kebendaan selain dari yang telah diatur dalam undang-undang ini Selain itu, 
hukum benda bersifat memaksa (dwingend recht), artinya harus dipatuhi, tidak boleh disimpangi, termasuk membuat peraturan baru yang menyimpang dari yang telah ditetapkan.

Penggunaan sertifikat pemakaian tempat usaha sebagai jaminan sendiri sudah berlangsung dari lama. Hal ini tidak seolah tidak terhindarkan dari semakin ramainya roda perekonomian di sektor mikro kecil dan menengah, tidak terkecuali pasar tradisional. Fenomena ini yang kemudian dimanfaatkan oleh dunia perbankan dalam menyalurkan kreditnya (Nurul Masfuhah, 2016: 254). Akan tetapi, kendala penyaluran kredit oleh lembaga keuangan perbankan terhadap pelaku usaha tersebut adalah mengenai jaminan. Para pelaku usaha tersebut menginginkan tambahan modal usaha tidak semuanya mempunyai jaminan berupa benda atau barang yang lembaga penjaminannya telah diatur dalam peraturan perundang-undangan (Nurul Masfuhah, 2016: 254). Tidak jarang para pelaku usaha atau calon debitor ini hanya mempunyai jaminan berupa tempat mereka berdagang atau berjualan (Nurul Masfuhah, 2016: 255).

Keberadaan tempat usaha atau kios ini dipandang memiliki nilai ekonomis. Oleh karena itu kreditor atau dalam hal ini bank dapat menerima tempat usaha pelaku usaha mikro kecil dan menengah untuk dijadikan jaminan. Padahal tempat usaha tersebut bukan milik para pelaku usaha tersebut, melainkan milik subjek hukum lain baik orang maupun badan hukum atau pemerintah yang dalam hal ini adalah pemerintah daerah. Khusus untuk tempat usaha yang dimiliki oleh pemerintah daerah biasanya diatur penggunaannya di dalam Peraturan Daerah (Perda). Kios dalam pasar merupakan salah satunya, para pelaku usaha mendapatkan ijin tertulis dari pemerintah daerah dengan berlandaskan pada Perda. Sebagai contohnya ada Perda Kabupaten Berau Nomor 13 Tahun 2011, Perda Kabupaten Bengkayang Nomor 6 Tahun 2010, Perda Kabupaten Jombang Nomor 25 Tahun 2010, Perda Kota Semarang Nomor 10 Tahun 2000, Perda Kota Madiun Nomor 32 tahun 2011, Perda DKI Jakarta Nomor 6 Tahun 1992, dan lain-lain. Penyebutan ijin penggunaan ini pun bermacam-macam, karena memang praktik ini terjadi di banyak daerah. Di samping tempat usaha milik pemerintah daerah, sekarang juga banyak tempat usaha yang merupakan kepimilikan orang atau badan hukum lain menggunakan sistem serupa. Yakni berupa sewa atas tanah dan bangunan yang berdiri di atasnya. atas hak yang timbul tersebut juga dibebani jaminan kepada pihak kreditor (bank).

Dengan demikian, seorang yang memiliki bangunan di atas tanah dengan hak sewa dapat menggunakan bangunan tersebut sebagai benda jaminan. Apabila pemilik tanah tidak bersedia memberikan persetujuan peralihan hak sewa kepada pihak lain, menurut Sumardi Mangunkusumo, hal ini tidak menjadi soal, akan tetapi nilai yang diberikan terhadap bangunan itu menjadi rendah sekali, karena yang dinilai bukan bangunannya akan tetapi bahan-bahan bangunannya, yaitu apabila debitor lalai memenuhi kewajibannya kreditor akan membongkar bangunan tersebut serta menjual bahan-bahan bangunan yang didapatkan (Oey Hoey Tiong, 1985: 60).

Apabila penjaminan tempat usaha ini dapat dilakukan dengan menggunakan lembaga jaminan fidusia maka tempat usaha yang dipakai oleh para pelaku usaha tidak dapat dibebani fidusia jika ditinjau dari pengertian benda dalam Pasal 1 Undang-Undang Fidusia. Hal ini dikarenakan hak kepemilikan tempat usaha tersebut bukan merupakan kepemilikan pelaku usaha. Lembaga gadai juga tidak dapat digunakan untuk mengikat sertifikat pemakaian tempat usaha sebagai jaminan. Hal ini dikarenakan tempat usaha sulit dikategorikan sebagai benda bergerak dan kekuasaan atas tempat usaha ini tidak dipindahtangankan kekuasaannya dari debitor kepada kreditor atau inbezitstelling.

Lebih lanjut, pembebanan jaminan terhadap sertifikat tempat usaha juga tidak bisa dibebani dengan Hak Tanggungan. Hal ini mengingat hak yang timbul dari pengunaan tempat usaha bukan termasuk hak yang diatur dalam UU Hak Tanggungan (Nurul Masfuhah, 2016: 265). Adapun hakhak atas tanah yang dapat dibebani dengan hak tanggungan adalah:
1. Hak Milik;
2. Hak Guna Usaha;
3. Hak Guna Bangunan; dan
4. Hak Pakai atas tanah negara. 
Keberadaan jaminan (collateral) merupakan kebutuhan bagi kreditor atas bank untuk memperkecil risiko dalam menyalurkan kredit, apabila debitor tidak mampu untuk menyelesaikan segala kewajiban yang berkenaan dengan kredit tersebut. Walaupun demikian, secara prinsip jaminan bukan persyaratan utama, bank memprioritaskan dari kelayakan usaha yang dibiayainya sebagai jaminan utama bagi pengembalian kredit sesuai dengan jadwal yang disepakati bersama (Johannes Ibrahim, 2004: 71).

Biasanya dalam perjanjian kredit dengan jaminan seperti ini disertakan grosse akta dalam akta perjanjian utang piutangnya. Grosse akta pengakuan utang tersebut tinggal dimintakan fiat eksekusi kepada Ketua Pengadilan Negeri. Pengikatan perjanjian kredit dengan grosse akta ini dilakukan di hadapan notaris yang ditunjuk oleh bank. Seringkali perjanjian kredit dengan grosse akta yang secara teori memiliki kekuatan eksekutorial akan menjadi perdebatan oleh hakim jika terjadi gugatan di pengadilan. Akan tetapi dalam praktiknya belum ada kasus perjanjian kredit dengan jaminan sertifikat pemakaian tempat usaha yang disertai grosse akta.

Adapun isi grosse akta pengakuan utang tersebut sebagai berikut (Delima Boru Manalu, 2007:88):

1. Jumlah utang, yakni perincian tentang jumlah kredit yang diberikan oleh bank kepada debitor, tujuan penggunaan kredit, cara penarikan kredit dan pembayaran kembali;

2. Biaya-biaya yang harus dibayar debitor yaitu berupa provisi dan biaya administrasi;

3. Jaminan utang, yaitu perincian jenis-jenis jaminan yang diberikan debitur untuk kredit yang bersangkutan;

4. Objek Jaminan disebutkan secara detail, oleh bank tidak hanya dicantumkan data kios pasar saja tetapi dimasukkan pula tabungan nasabah debitor sebagai jaminan tambahan;

5. Hak dan kewajiban yaitu hak dan kewajiban bank selaku kreditor dan pedagang selaku debitor;

6. Kuasa untuk menjual barang yang tersebut dalam klausul jaminan. Termasuk perbuatan hukum yang dianggap wajar dan perlu adalah Pihak Debitur memberikan kuasanya kepada Bank untuk memperpanjang ijin menempati tempat usaha apabila ternyata ijin sudah hampir habis sementara tempat usaha masih menjadi jaminan kredit.

Meskipun belum ada kasus hukum yang terjadi, hukum harus segera menyediakan jalan keluar apabila ke depannya terjadi kasus hukum. Oleh karenanya instrumen hukum yang mengatur kredir-kredit untuk pelaku usaha mikro kecil dan menengah seperti ini harus disediakan. Walaupun juga potensi kasus kredit macet yang terjadi bisa dihindari mulai dari pemberian kredit itu sendiri. Bank sebagai kreditor wajib menggunakan indikator-indikator dalam prinsip pemberian kredit. Baik prinsip 3R (Returns, Repayment, and Risk Bearing Ability), Prinsip 5C (Character, Capacity, Capital, Collateral, and Condition of Economy), maupun prinsip 7P (Personality, Party, Purpose, Prospect, Payment, Profitability, and Protection).

\section{Simpulan}

Berdasarkan analisis di atas, maka dapat disimpulkan sebagai berikut:

1. Kedudukan sertifikat tempat usaha sebagai jaminan dalam perjanjian kredit adalah kurang tepat. Karena tempat usaha tersebut bukan milik pelaku usaha secara hukum. Hal ini juga mengingat 'kepemilikan' atas tempat usaha tersebut tidak sama sekali diatur hak kebendaannya di dalam Buku II KUHPerdata yang memiliki sifat tertutup. Maka dari itu atas tempat usaha tersebut tidak dapat dibebani oleh lembaga jaminan apapun yang telah ada dan diatur oleh undang-undang. Baik melalui Hak Tanggungan, Fidusia, Gadai, maupun Hipotek. Hal ini juga tercermin dari penggunaan grosse akta yang dengan kata lain memaksa debitor untuk secara sepihak mengakui sedang memiliki utang kepada kreditor, mengingat grosse akta pengakuan utang memiliki kekuatan eksekutorial. 
2. Kerancuan hukum yang berpotensi timbul dari praktik hukum ini, maka jika terjadi wanprestasi akan sangat rumit. Upaya penyelesaian hukum apabila terjadi wanprestasi dari debitor atas perjanjian kredit dengan jaminan sertifikat pemakaian tempat usaha dapat ditempuh melalui dua cara, yakni negosiasi dan litigasi. Mengingat kredit diberikan kepada debitor sebagai pelaku usaha mikro kecil dan menengah maka upaya negosiasi masih diutamakan oleh bank karena memang jumlah kredit yang diberikan relatif kecil. Cara negosiasi dapat dilalui dengan reconditioning dan rescheduling kredit yang mana debitor mengalami kesulitan membayar. Apabila setelah dilakukan upaya negosiasi yang persuasif debitor masih mengalami kesulitan membayar sisa utangnya maka akan dilakukan eksekusi melalui grosse akta pengakuan utang dengan memintakan fiat eksekusi kepada Ketua Pengadilan Negeri. Atau dengan cara lain yakni mengajukan gugatan wanprestasi kepada debitor di pengadilan negeri setempat.

\section{E. SARAN}

Untuk memitigasi potensi ketidakjelasan hukum karena kaburnya hukum yang menjadi dasar perjanjian kredit dengan jaminan tempat usaha, maka hal berikut dapat dilakukan:

1. Pembuat Undang-undang dalam hal ini Pemerintah dan Dewan Perwakilan Rakyat diharapkan memberikan ketentuan yang mendetail dan mengatur pemberian kredit dengan cara pengikatan jaminan berupa tempat usaha. Serta memberikan perlindungan hukum baik bagi kreditor maupun debitor dalam melaksanakan perjanjian kredit dengan jaminan tempat usaha. Demi mendorong bertumbuhnya ekonomi dan menjamin hadirnya keadilan dan kepastian hukum

2. Sebaiknya bank selaku kreditor mengedepankan proses negosiasi dan non litigasi lainnya apabila terjadi wanprestasi oleh debitor. Dan sejak awal memberikan pemahaman mengenai hak dan kewajiban yang timbul dari perjanjian kredit tersebut.

\section{F. Daftar Pustaka}

Delima Boru Manalu. 2007. "Kios Pasar Sebagai Jaminan Kredit Perbankan di PT Bank UOB Buana Cabang Semarang". Naskah Publikasi. Semarang: Universitas Diponegoro.

Johannes Ibrahim. 2004. Bank sebagai Lembagai Intermediasi dalam Hukum. Bandung: Positif. CV Utomo.

Muliaman D. Hadad. 2017. "Financial Technology (Fintech) di Indonesia", Kuliah Umum tentang FintechIBS, Otoritas Jasa Keuangan, Jakarta, Volume 1 Nomor 2.

Neni Sri Imaniyati. 2010. Pengantar Hukum Perbankan di Indonesia. Bandung: Reika Aditama.

Nurul Masfuhah. 2016. "Kios Pasar sebagai Objek Jaminan Kredit", Arena Hukum. Vol. 9 No. 2. Surabaya, FH Universitas Surabaya.

Oey Hoey Tiong. 1985. Fiducia sebagai Jaminan Unsur- unsur Perikatan. Jakarta: Ghalia Indonesia.

Peter Mahmud Marzuki. 2014. Penelitian Hukum. Jakarta: Prenadamedia Group.

Ratna Widayati dan Septi Maiwati. 2019. "Aktivitas Pemberian Kredit Komersil pada Bank Nagari Cabang Sijunjung”. OSF Preprints. 28 Februari 2019. doi: 10.31219/osf.io/fnxaj.

Riyo Wuryanto. 2018. "Efektivitas Grosse Akta Pengakuan Hutang dalam Praktik Pemberian Kredit Perbankan di Surakarta". Jurnal Repertorium Volume 5 Nomor 1.

Shendy Vianni Rangian. 2015. "Pelaksanaan Eksekusi Grosse Akta Pengakuan Hutang dalam Penyelesaian Sengketa Kredit Macet Perbankan". Jurnal IImiah Mahasiswa Universitas Surabaya Volume 4 Nomor 1. Maret 2015. 